\title{
DOS TACHOS E PANELAS AOS AÇUCAREIROS E BULES. RECIPIENTES PARA CONFECCIONAR E SERVIR ALIMENTOS EM PORTUGAL NA ÉPOCA MODERNA
}

\author{
From Cupper Pans to Sugar Pots and Tea Pots. \\ Containers to Prepare and Serve Food in \\ Portugal in Modern Times
}

Isabel M. R. Mendes Drumond Braga*

\begin{abstract}
RESUMO
Neste artigo, pretende estudar-se, a partir de fontes diversificadas, tais como livros de cozinha e inventários de bens, as baterias de cozinha e as baixelas enquanto elementos que patenteiam níveis de vida, hábitos, padrões de consumo e maneiras de cozinhar dos diversos grupos sociais.

Palavras-chave: baixela; bateria de cozinha; Portugal.
\end{abstract}

\begin{abstract}
This article aims to approach from diversified sources such as kitchen books and goods inventories, kitchen batteries and sets of dishes as items which evidence living standards, habits, consumption patterns and cooking of the several social groups.
\end{abstract}

Key-words: set of dishes; kitchen battery; Portugal.

1. Se bem que a história das práticas alimentares e da sociabilidade à mesa tenha vindo a merecer atenção por parte dos investigadores portugueses nos últimos anos ${ }^{1}$, um dos assuntos que menos interesse tem

Professora Auxiliar com Agregação e de nomeação definitiva da Faculdade de Letras da Universidade de Lisboa. Endereço: Faculdade de Letras da Universidade de Lisboa. Alameda da Universidade 1600-124 LISBOA PORTUGAL. isabeldrumondbraga@hotmail.com

1 Sobre a produção historiográfica a respeito desta temática, cf. BRAGA, Isabel M. R. Mendes Drumond. Alimentação e sociabilidade à mesa: um percurso historiográfico recente. In: COLÓQUIO DE HISTÓRIA E CULTURA DA ALIMENTAÇÃO: "SABER E SABOR... HISTÓRIA, COMIDA E IDENTIDADE", 1. Anais... Curitiba, 2007. 
despertado respeita aos recipientes usados para confeccionar e servir os alimentos. Para o efeito, é essencial o cruzamento de dados arquivísticos - tais como os que se podem obter nos inventários de bens e nos livros de cozinha - com a iconografia e com as fontes materiais. Se, para épocas mais próximas, restam peças integrantes das baterias de cozinha, a par de pratas, porcelanas, cristais e mobiliário ligado à preparação dos alimentos e ao serviço da mesa - objectos utilizados pelos grupos privilegiados e guardados sobretudo em museus e em colecções particulares -, o contributo da arqueologia é naturalmente enriquecedor na medida em que se poderão revelar utensílios mais antigos de preparação e serviço dos alimentos, de utilização corrente em espaços populares, religiosos e aristocráticos, pois os testemunhos arqueológicos resultam directamente das vivências humanas. Neste sentido, a arqueologia, a arqueozoologia e a paleobotânica poderão ajudar a esclarecer as práticas alimentares, os consumos de determinados grupos e o modo de preparar os alimentos, em especial nas épocas medieval e moderna ${ }^{2}$.

Quer a bateria de cozinha quer as baixelas anunciem a presença ou ausência de objectos comuns e de luxo, consequentemente patenteiam níveis de vida, hábitos, padrões de consumo e também maneiras de cozinhar. Por exemplo, grelhas e espetos revelam a prática dos grelhados, chocolateiras, o hábito de beber chocolate, serviços de chá e café, o consumo das outras chamadas bebidas exóticas etc. Ora, se qualquer abordagem à história da alimentação pressupõe a consciência da produção e distribuição dos produtos alimentícios, da sazonalidade de certos bens, das incipientes técnicas de conservação dos produtos alimentares, do estádio de desenvolvimento das técnicas culinárias e, naturalmente, do poder de compra dos diferentes grupos consumidores, também é verdade que a bateria de cozinha e a baixela de cada um evidenciam vivências e situações, ou seja, podem ser entendidas

2 Vejam-se alguns estudos em que essa realidade está bem patente: GOMES, Mário Varela; GOMES, Rosa Varela; CARDOSO, João Luís. Aspectos do quotidiano numa casa de Silves durante o século XV. Xelb, Silves, v. 3, p. 33-78, 1996; GOMES, Rosa Varela. Cerâmica muçulmana do Castelo de Silves. Silves: Câmara Municipal, 1988 (=Xelb, Silves, v. 1, 1988). RIBEIRO, Margarida Ribeiro. Olaria de uso doméstico na arquitectura conventual do século XVI. Montemor-o-Novo: Grupo de Amigos de Montemor-o-Novo, 1984; FERREIRA, Fernando E. Rodrigues. Ensaio para uma leitura económica e social do contexto arqueológico de São Vicente de Fora. Olisipo, Lisboa, 2. série, n. 6, p. 11-38, 1998; Comer en Ceutta en el siglo XIV. La Alimentación durante la época Marini. RUIZ, José Manuel Hita; PADILLA, José Suárez; PAREDES, Fernando Villada (Coords.). Ceuta: Ciudad Autónoma de Ceuta, Museu de la Basílica Tardoromana, 2009. 
como critério para aferir o estatuto social dos seus possuidores. Neste texto, concentraremos as nossas atenções especialmente nas fontes arquivísticas, sem descurar alguma iconografia e um ou outro dado arqueológico.

2. Para épocas mais recuadas, os livros de receitas culinárias, os regimentos de colégios e os inventários de bens permitem ter algumas ideias acerca dos profissionais da arte culinária e dos objectos de que se serviam ${ }^{3}$. A partir do Livro de cozinha da Infanta D. Maria - do final do século XV, início do século XVI -, podemos também imaginar o recheio de uma cozinha principesca. Ali se encontrariam albarradas de bico, alguidares, bacias, bacios, borcelanas, canudos ou paus roliços (rolos da massa), canivetes, carretilhas, colheres de prata, escudelas, escumadeiras, fusos ou furadores, graais, joeiras, panelas, peneiras de seda, pratos, púcaros, rapadouras, sertãs, tachos, tigelas e vasilhas de diversos tamanhos ${ }^{4}$.

Outras fontes são igualmente relevantes. Através do inventário dos bens da Infanta D. Beatriz, mãe do rei D. Manuel I, falecida em 1506, podemos conhecer uma boa parte do recheio da sua cozinha: açafates, alguidares de Estremoz, de pedra, de vidro e vidrados; almofariz, almofias, bacios de Valença, barris, búrneas, caldeiras, caldeirões, cestos, colheres de ferro, bandejas, escudelas, escumadeiras, funis de cobre, graais de pedra, obradeiras de obreias, pratos de estanho, pedras mármore, potes, púcaros de barro, ralos de folha de flandres, sertãs, tachos de cobre e de ferro de vários tamanhos, tabuleiros, vasilhas de barro e de chumbo, sem esquecer assadores de castanhas, espetos, fogareiros de ferros de diversos tamanhos, fornos de pastéis, grelhas e trempes. Para o serviço da mesa, a infanta contava com prataria diversa branca e dourada: açucareiros, barris, caçoilas, caixas para confeitos, castiçais, colheres, garfos ${ }^{5}$, gomis, pratos e salseiras. Os vidros, brancos e de cores, também faziam parte dos bens, nomeadamente: castiçais, copas, bacios com gomil, enfusas, escudelas, jarros, potes e púcaros

3 Sobre esta realidade em França, cf. DE FRAMOND, Martin. A Table d'un Marchand Bourgeois du Puy. Le Boire et le Manger au XVI siècle. Actes du Colloque du Puy-en-Velay, estudos reunidos e apresentados por Marie Viallon-Schoneveld. Saint Etienne: Universidade de Saint Etienne, 2004, p. 111-114, 142-144.

4 SANTOS, Maria José Azevedo. O mais antigo livro de cozinha português - receitas e sabores. Apresentado nas Jornadas Bem-Dizer e Bem-Comer, Coimbra 29/11 a 01/12 de 199, p. 35-66.

5 A presença de talhares no inventário mostra a precocidade da sua adopção em Portugal entre os privilegiados. Sobre esta realidade em termos europeus, cf. SARTI, Raffaella. Casa e família. Habitar, comer e vestir na Europa moderna. Trad. Isabel Teresa Santos. Lisboa: Estampa, 2001, p. 252-253. 
FIGURA 1 - FOLIO DO LIVRO DE COZINHA DA INFANTA D. MARIA.

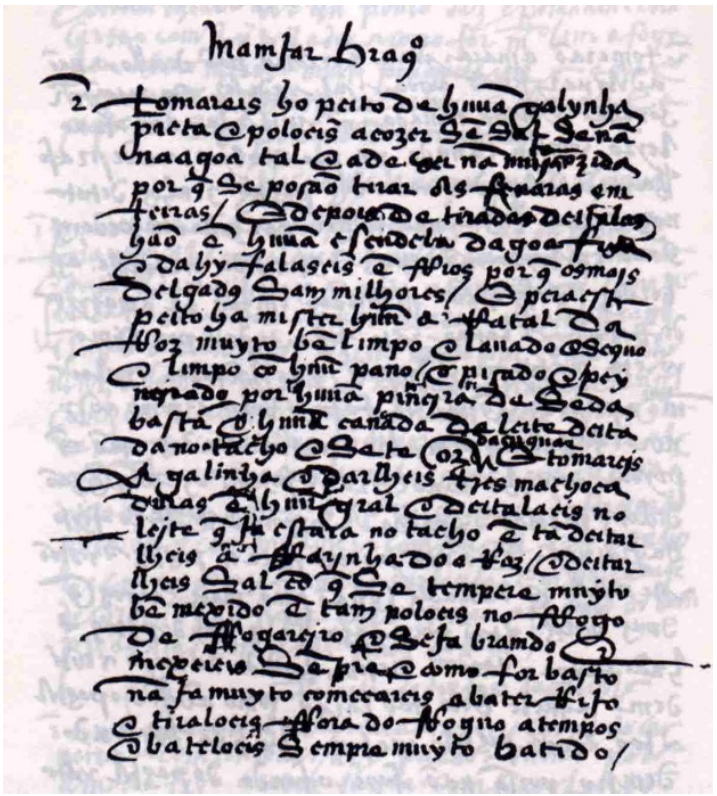

com tampa. Havia ainda alcatifas, almofadas, panos de armar, toalhas de mesa de damasco e de pano de Holanda bordadas com seda e ouro e até um braseiro de prata ${ }^{6}$.

A infanta D. Beatriz, mãe do monarca, possuía um recheio de casa que em nada seria inferior ao do rei D. Manuel $\mathrm{I}^{7}$. A riqueza proporcionada pelo comércio ultramarino e a facilidade em obter especiarias e outros produtos de luxo para a mesa, tais como porcelanas ${ }^{8}$, apenas após sete viagens

6 FREIRE, Anselmo Braamcamp. Inventário da Infanta D. Beatriz. 1507. Archivo Historico Portuguez, Lisboa, v. 9, p. 64-110, 1914.

7 Sobre a casa da infanta, cf. PEREIRA LOPES, Sebastiana Alves. O Infante D. Fernando e a nobreza fundiária de Serpa e Moura (1453-1470). Beja: Câmara Municipal de Beja, 2003, e OLIVEIRA E COSTA, João Paulo. D. Manuel I (1469-1521). Um Príncipe do Renascimento. Lisboa: Círculo de Leitores, Universidade Católica Portuguesa, Centro de Estudos dos Povos e Culturas de Expressão Portuguesa, 2005.

8 Sobre este ambiente de luxo, sofisticação e exotismo na corte de D. Manuel, cf. OLIVEIRA E COSTA, João Paulo. D. Manuel I (1469-1521) [...]. 
ao Oriente (1497-1499, 1500-1501, 1501-1502, 1502-1503, 1503-1504 e $1504-1505$ e $1505-1506)^{9}$ começaram a evidenciar um certo grau de exotismo e de sofisticação que será, naturalmente, mais visível durante o reinado de D. João III, quando os portugueses alcançaram a China e o Japão, como se pode testemunhar pelos inventários de bens da rainha $\mathrm{D}$. Catarina.

Quando D. Manuel I casou a sua filha, D. Beatriz, com o duque de Saboia, em 1521, também foram bem visíveis as peças luxuosas que integraram o dote da infanta. No grupo das pratas douradas, contaram-se albarradas, atanares, bacias, bacios de água às mãos, barnagais, barris, braseiros, caçoulas, castiçais, colheres, confeiteiras, copos, escalfadores, escudelas, escumadeiras, especieiros, frascos, garfos, gomis, jarros, oveiros, pichéis, pivetes, pratos, saleiros, salseirinhas, salvinhas e taças. Todos estes objectos eram de prata dourada. De referir ainda toalhas e guardanapos de pano de Holanda e pano de Bretanha e ainda "hua caxa grande de pao com seus repartimentos pera a specearia guarnecida com sua fechadura e chaves"10. A infanta levou para Saboia diversas peças de cobre para uso na cozinha, a saber: quatro tachos de cozer peixe, outros tantos para manjar branco, quatro bacias para lavar carne e ainda três tachos, duas escumadeiras, duas caçoilas, dois caldeirões, quatro panelas, um funil, dois fornos com trempes e quatro cântaros. Juntem-se ainda, de ferro ou com partes de ferro: almofarizes, assadores, barris, colheres grandes, cutelos, escapolas, espetos, ferros para bolos, gadanhos, gorivaldos, graais, grelhas, navalhões, pás, peneiras, pingadeiras, rapadouras, sertãs, tábuas para pastéis, tenazes e trempes. Seguiram ainda ceirões de esparto ${ }^{11}$. Entre os bens pertencentes a D. Manuel I, à data da sua morte, em 1521, contaram-se diversas peças de mesa, tais como bacios de água às mãos com e sem gomil, bacios de pé, castiçais, escudelas, garrafas, púcaros, salvas, garfos e colheres. Todos estes objectos eram de prata branca ou dourada, alguns com esmaltes e com as armas reais e, em alguns casos, com temas ligados às conquistas e,

9 Cf. PISSARRA, José Virgilio Amaro. A Armada da Índia. Cômputo, tipologia e funcionalidade das Armadas de Guerra Portuguesas do Oriente (1501-1510). Dissertação (Mestrado em História dos Descobrimentos e da Expansão Portuguesa) - Faculdade de Letras da Universidade de Lisboa. Lisboa, 2001, p. 276-299.

10 SOUSA, D. António Caetano de. Provas da história genealógica da Casa Real Portuguesa, tomo 2, parte 2, Coimbra: Atlântida, 1948, p. 27-81.

11 SOUSA, D. António Caetano de. Provas da história genealógica [...], tomo 2, parte 2, p. $27-81$. 
consequentemente, aos novos espaços ${ }^{12}$. Para limpar as mãos eram utilizadas toalhas de pano de Holanda ${ }^{13}$.

O património de D. Catarina, consorte de D. João III, no que se refere ao recheio da cozinha e às peças que iam à mesa, era sumptuoso. No primeiro caso contam-se, entre outros: açafates, açucareiros, alguidares, almaraias, almofarizes, almofias, bacios de cozinha, balanças, barris, caçoilas, cestos, colheres, recipientes de preparar cuscuz (denominados cuscuzeiros), escalfadores, escudelas, escumadeiras, fusos de mexer conservas, facas para sal, galhetas, garfos, grelhas, medidas de vários tamanhos, panelas, taças, vinagreiras. Ao serviço da mesa estavam bacias de água às mãos, bacios, bandejas, caçoilas, castiçais, colheres, confiteiras, escudelas, fruteiros, garfos, garrafas, jarros, pratos, saleiros, salseirinhas e até uma fonte para decoração ${ }^{14}$. A rainha possuía ainda mobiliário indiano e chinês, guadamecis, tapeçarias europeias e asiáticas e uma profusão de panos e almofadas de seda.

Além da prataria, alguns dos objectos arrolados nos inventários eram de tartaruga, laca, madrepérola e porcelana, que começou a chegar a Portugal logo após a primeira viagem de Vasco da Gama. Sabe-se, por exemplo, que entre fevereiro de 1511 e abril de 1514 o tesoureiro das especiarias da Casa da Índia recebeu 692 peças de porcelana. A estes números há que

12 FREIRE, Anselmo Braamcamp. Inventário da Guarda-Roupa de D. Manuel. Archivo Historico Portuguez, Lisboa, v. 2, p. 391-392, 1904. Sobre a decoração de algumas peças, cf. ANDRADE, Maria do Carmo Rebelo de. Iconographic Narrative of Stately Silverware Portugueses XV and XVI centuries. Mesas Reais Europeias. Encomendas e Ofertas/Royal and Princely Tables of Europe. Comissions and Gifts/Tables Royales en Europe. Commandes et Cadeaux. Coordenação de Leonor d' Orey. Lisboa: Instituto Português de Museus, 1999, p. 44-57.

13 FREIRE, Anselmo Braamcamp. Inventário da Guarda-Roupa [...], p. 398.

14 A publicação dos vários inventários de bens da Rainha e dos resumos de muitos documentos guardados na Torre do Tombo, bem como o seu estudo, foram objecto de atenção por parte de GSCHWEN, Annemarie Jordan. The Development of Catherine of Austria's Collection in the Queen's Household: His Character and Cost, 2 v. Washington: Brown University, 1994. A mesma autora tem vindo a repetir, e em alguns casos a antecipar, estas informações em diversos trabalhos. Cf., por exemplo, Idem, Catarina de Áustria: colecção e Kunstkammer de uma princesa renascentista, Oceanos, Lisboa, v. 16, p. 62-70, 1993, p. 62-70; Idem, As maravilhas do Oriente: colecções de curiosidades renascentistas em Portugal. A Herança de Rauluchantim, Lisboa: Comissão Nacional para as Comemorações dos Descobrimentos Portugueses, Misericórdia de Lisboa, 1996, p. 82-127; Idem, Os produtos exóticos da carreira da Índia e o papel da Corte Portuguesa na sua difusão. Nossa Senhora dos Mártires. A Última Viagem, Lisboa, Expo 98, Verbo, 1998, p. 123-141. Idem, Queen of the Seas and Overseas Dining at the Table of Catherine of Austria, Queen of Portugal. Mesas Reais Europeias. Encomendas e Ofertas/Royal and Princely Tables of Europe. Comissions and Gifts/Tables Royales en Europe. Commandes et Cadeaux. Coordenação de Leonor d' Orey. Lisboa: Instituto Português de Museus, 1999, p. 14-43. 
acrescentar as que eram de particulares e cuja quantidade se desconhece ${ }^{15}$. Recorde-se o testemunho dos cavaleiros Tron e Lippomani que, em 1580, notaram a existência de diversas lojas da rua Nova (Lisboa) onde se podiam adquirir objectos orientais: "porcelanas finíssimas de vários feitios, conchas, cocos lavrados de diversos modos [e] caixinhas guarnecidas de madrepérola" ${ }^{16}$. Pela mesma fonte, ficamos ainda informados que "a prata de Lisboa é lavrada com delicadeza e variedade por ser costume, assim entre nobres como entre plebeus, usarem de pratos e bacias de prata"17.

A descrição dos banquetes oferecidos por D. Sebastião e por D. Catarina em 1565, por ocasião do casamento de D. Maria, neta de D. Manuel I e filha do infante D. Duarte, com Alessandro Farnese ${ }^{18}$ fornece igualmente dados de interesse. O relato destas refeições festivas foi feito por Francesco de Machi, que também registou o banquete nupcial servido a 18 de novembro de 1565 , em Bruxelas, o qual contou com o trabalho de 110 cozinheiros, que trabalharam durante 15 dias $^{19}$. Fixemo-nos nos banquetes da corte de D. Sebastião descritos por Machi. A refeição oferecida pelo monarca foi acompanhada por música e

[...] teve lugar na sala real, onde se tinha erguido um anfiteatro de madeira, com sete ou oito degraus, o qual rodeava toda a sala, estando tanto esta, como aquele, forrados por finíssimas tapeçarias de ouro, prata e seda, coisa riquíssima e de grande vulto, atendendo ao tamanho da sala e ao do anfiteatro. Neste

15 DIAS, Pedro. Símbolos e imagens do Cristianismo na porcelana chinesa. Reflexos. Catálogo. Lisboa: Misericórdia de Lisboa, Comissão Nacional para as Comemorações dos Descobrimentos Portugueses, 1996, p. 17-59.

16 Viagem a Portugal [...], p. 366.

17 Viagem a Portugal [...], p. 366.

18 Sobre o casamento, a viagem e o recebimento de D. Maria, cf. BERTINI, Giuseppe. L'Entrata Solenne di Maria di Portogallo a Parma nell 1566. D. Maria de Portugal Princesa de Parma (1565-1577) e o seu tempo. As relações culturais entre Portugal e a Itália na segunda metade de Quinhentos. Porto: Centro Interuniversitário de História da Espiritualidade, Instituto de Cultura Portuguesa, 1999, p. 69-84; Idem, The Marriage of Alessandro Farnese and D. Maria of Portugal in 1565: Court Life in Lisbon and Parma. Cultural Links between Portugal and Italy in the Renaissance. Direcção de K. J. P. Lowe. Oxford: Oxford University Press, 2000, p. 45-59.

19 BERTINI, Giuseppe. O "Livro de Cozinha" de Maria de Portugal e a Cozinha de Corte em Bruxelas e em Lisboa ao tempo das suas núpcias com Alexandre Farnésio. Oceanos, Lisboa, v. 21, p. 119-125, 1995. Cf. também D. Maria de Portugal (1538-1577) Princesa de Parma. Monumenta Sparsa. Direcção de José Adriano de Freitas Carvalho. Porto: Centro Interuniversitário de História da Espiritualidade, 1998 , p. 100. 
havia um baldaquino recamado de pérolas de espaço a espaço, sob o qual estava uma cadeira com almofadas guarnecidas de ouro e o chão coberto com tapetes de seda. Ao pé havia duas grandes credenciais, fechadas por uma balaustrada, cada uma com oito degraus e por cima das quais estavam dois dóceis de tela de ouro, estando numa uma baixela de vasos dourados, com alguns jarros, bacias, taças e copos de ouro maciço, e na outra um grande jarro e bacia de ouro puro, cravejado de pedras preciosas de enorme valor, digno, na verdade, de um imperador. De forma que não se cansavam os olhos de admirar esta grande e riquíssima credencia, ornamentada com tão copioso número de copos, bacias, jarras, frascos, taças, candelabros, tudo isto com profusão de subtis e vários lavoures de folhagens e diversos esmaltes, sendo os trinchadores dourados e alguns de ouro maciço. Era a outra credencia de igual tamanho, e com vasos da mesma riqueza, toda ela cheia de baixela de prata, polida como um espelho, mas estas duas credencias estavam desta forma somente por grandeza e pompa real, porque nas cozinhas havia uma outra baixela, composta de um sem número de pratos, taças e outros géneros de peças adequadas ao serviço da mesa ${ }^{20}$.

Em simultâneo, outro aposento do palácio real foi palco de outro banquete cuja anfitriã foi a rainha $\mathrm{D}$. Catarina. De Machi notou que a refeição foi igualmente sumptuosa e que também foi exibida uma enorme quantidade de peças douradas. $\mathrm{O}$ aposento fora igualmente decorado a preceito: "riquissimamente adornado com tapeçarias de ouro, prata e seda, com um baldaquino de brocado de ouro" 21 .

A mesa de uma refeição de luxo apresentada na sala de jantar enquanto espaço específico e permanentemente dedicado às refeições só foi uma realidade no século XVIII ${ }^{22}$. Antes, mesmo nos palácios renascentistas, as salas eram multifuncionais. Aí se armava a mesa, a qual também podia ser posta nos aposentos privados, nomeadamente câmaras e antecâmaras. A mesa dos abastados era sempre montada em espaços ricamente decorados.

20 TOMÁS, Fernandes. Cartas Bibliographicas, 2. Série. Coimbra: Imprensa da Universidade, 1877 , p. $53-54$.

21 TOMÁS, Fernandes. Cartas [...], p. 55.

22 THIEBAUT, Philippe. 1850-1914. La table bourgeoise. Histoire de la table. Paris: Flammarion, 1994, p. 253-264; SARTI, Raffaella. Casa e família. Habitar, comer e vestir na Europa moderna. Trad. Isabel Teresa Santos. Lisboa: Estampa, 2001, p. 226. 
No chão eram colocadas alcatifas ou esteiras e, nas paredes, tapeçarias ou guadamecis, de acordo com as estações frias ou quentes, respectivamente. Por vezes, construía-se um estrado com alguns degraus, o qual era posteriormente coberto. A iluminação através de castiçais e candelabros de prata, assegurando fins práticos e fomentando uma atmosfera festiva e até cerimonial $^{23}$, era uma realidade, daí os elevados gastos com cera ${ }^{24}$. O recurso a pequenas construções efémeras, como os dosséis e o uso de panos de armar, também era frequente. Posto isto, colocava-se a mesa, frequentemente rectangular, coberta com toalha, em princípio branca, mesmo quando a mesa já apresentava algum pano rico bordado, por exemplo, com seda e ouro. Sobre a toalha aparecem sempre objectos emblemáticos das refeições: a faca e o saleiro $^{25}$, este último por vezes decorado com elementos marinhos ou em forma de concha. Mais raramente, com formas zoomórficas da fauna de novas paragens, como certo saleiro de cristal indiano ornamentado com dois jacintos e com ouro, oferecido pela rainha D. Catarina a sua nora D. Joana, em $1553^{26}$. Perto da mesa, expunham-se os utensílios, especialmente os de prata, sobre móveis diversos para evidenciar a riqueza da casa. Cadeiras e almofadas completavam o quadro. Em momentos festivos, a refeição era acompanhada por música.

Deixemos a realeza e aventuremo-nos pelos inventários de bens de outras pessoas. Por exemplo, à morte do governador do Brasil, Mem de Sá, em 1572, foi dado destino aos bens que ficaram no seu engenho de Sergipe. Pela lista dos mesmos, podemos ter alguma noção de parte dos utensílios que integravam a cozinha. De cobre: uma batedeira, uma coadeira, duas escumadeiras e um pote. De latão: uma bacia grande, balanças, uma caldeira

23 DUARTE, Marco Daniel. O Rei preside à Ceia. Estudo iconológico da Mesa Real na Idade Moderna. Economia, sociedade e poderes. Estudos em homenagem a Salvador Dias Arnaut. Coordenação de Leontina Ventura. Coimbra: Comissão Científica do Grupo de História da Faculdade de Letras da Universidade de Coimbra, 2002, p. 725.

24 Veja-se por exemplo, os gastos com cera, por parte da rainha D. Catarina. Cf. MENDES, Isabel M. R. O “deve" e o "haver" da casa da Rainha D. Catarina (1525-1557). Arquivos do Centro Cultural Português, Lisboa/Paris, n. 28, p. 171, 1990.

25 Sobre esta realidade, cf. PALLA, Maria José. Cozinhar e contar uma história. O imaginário alimentar em Gil Vicente. In: CONGRESSO DAASSOCIAÇÃO INTERNACIONAL DE LUSITANISTAS, 5. Actas... Organização e coordenação de T. F. Earle. Oxford/Coimbra, 1998, p. 1190 e 1191; Idem. Comida em Portugal no Limiar do Novo Mundo. À volta da mesa. Os alquimistas do prazer. Lisboa: Instituto do Emprego e Formação Profissional, 2004, p. 33.

26 GSCHWEND, Annemarie Jordan. A cristal elephant from the Kunstkammer of Catherine of Austria. Jahrbuch der Kunsthistorischen Sammlungen in Wien, Viena, band 87, p. 121-126, 1991. 
e dois tachos. De estanho: dois bacios de cozinha grandes, dois bacios de água às mãos, 31 bacios, duas galhetas, garrafas, três pichéis e sete pratos. De ferro: duas colheres, seis espetos de ferro, um garfo, grelhas de ferro e três rapadouras. Toalhas de mesa e oito guardanapos de Flandres completam o rol dos bens que, em 1574, ainda não tinham sido vendidos ${ }^{27}$.

Se a iconografia quinhentista nos mostra uma mesa relativamente simples $^{28}$, tal explica-se pelo facto da ostentação através da baixela concentrar-se na copa e não na própria mesa, situação que só irá ser cabalmente alterada no século XVIII. Efectivamente, as pinturas quinhentistas que apresentam mesas constituem claras transposições de episódios bíblicos para a época em que o pintor viveu. Logo, ao olharmos para as representações da Última Ceia, do Banquete de Herodes ou de Cristo em Casa de Marta, independentemente das questões de autoria destas obras ${ }^{29}$, estamos a apreciar a ambiência própria do século XVI, o que converte as cenas ali representadas em episódios domésticos. A realidade política, social e cultural da época está ali presente. Assim, estamos perante discursos pictóricos realistas que pretendiam possibilitar o diálogo com quem observava a pintura. Notem-se as mesas rectangulares, mais raramente redondas, montadas sobre estrados e revestidas com toalhas brancas, em alguns casos colocadas sobre outras toalhas ricamente decoradas, bem como a presença da multifuncional faca e, em alguns casos, de guardanapos, saleiros e frutos.

Mais modesta é a informação acerca das peças de cozinha utilizadas para confeccionar as refeições dos estudantes do Colégio das Artes, de Coimbra. No regimento, não datado mas posterior a 1574, faz-se saber que as viandas deveriam obrigatoriamente ser cozinhadas em recipientes de barro. A única excepção aceita era o peixe, que poderia ser preparado em peças de cobre estanhado ${ }^{30}$.

27 FRANÇA, Paula Cristina Viana; PEREIRA, Ilídio Manuel Barbosa. Um livro do Brasil no Arquivo Histórico Municipal de Coimbra: Engenho de açúcar em Sergipe (1574-1578). Revista Portuguesa de História, Coimbra, v. 33, p. 229-231, 1999.

28 Sobre a análise iconográfica da mesa, cf. DUARTE, Marco Daniel. O Rei preside à ceia [...], p. 705-751 e MIRET I NIN, Monserrat. O vinho na arte. Trad. e rev. de Daniel Gouveia. Lisboa: Chaves Ferreira, 2005.

29 Sobre a actividade de Vasco Fernandes, cf. RODRIGUES, Maria Dalila Aguiar. Modos de expressão na pintura portuguesa. O processo criativo de Vasco Fernandes (1500-1542). 2 v. Dissertação (Doutoramento em História da Arte) - Faculdade de Letras da Universidade de Coimbra. Coimbra, 2000.

30 BRANDÃO, Mário. O Colégio das Artes (1555-1580). Coimbra: Imprensa da Universidade, 1933, p. CXXIX. 


\section{FIGURA 2 - FRANCISCO HENRIQUES EM PARCERIA COM VASCO FERNANDES - ÚLTIMA CEIA (1501-1506). VISEU, MUSEU DE GRÃO VASCO.}

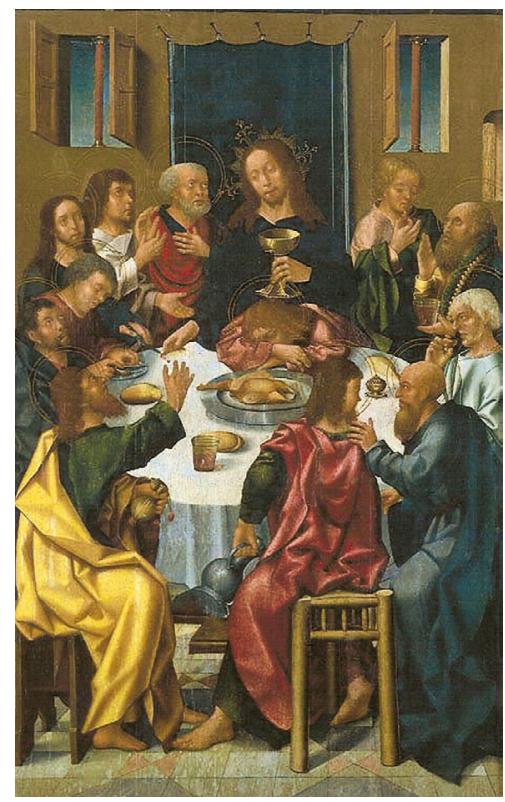

A arqueologia também fornece dados de muito interesse. Por exemplo, conhece-se bastante olaria comum produzida em Montemor-o-Novo, durante o século XVI. Efectivamente, no convento de São Domingos daquela localidade foram encontradas peças de diferentes tipologias, a saber: alguidares, asados, atanores, barris, caçoulas, fogareiros, infusas, panelas, pias de cântaros, potes de adega, pucarinhos, quartas, talhas, tarros, tigelas e $\operatorname{tachos}^{31}$.

3. Para as centúrias seguintes, as fontes são mais abundantes. Se concentrarmos as nossas atenções nos livros de cozinha, poderemos verificar a presença de diferentes peças para preparar e servir os alimentos. Por

31 RIBEIRO, Margarida. Olaria de uso doméstico na arquitectura conventual do século XVI [s.1.]. Edição do Grupo de Amigos de Montemor-o-Novo, 1984. 
FIGURA 3 - GASPAR VAZ - CRISTO EM CASA DE MARTA. CERCA DE 1535. VISEU, MUSEU DE GRÃO VASCO.

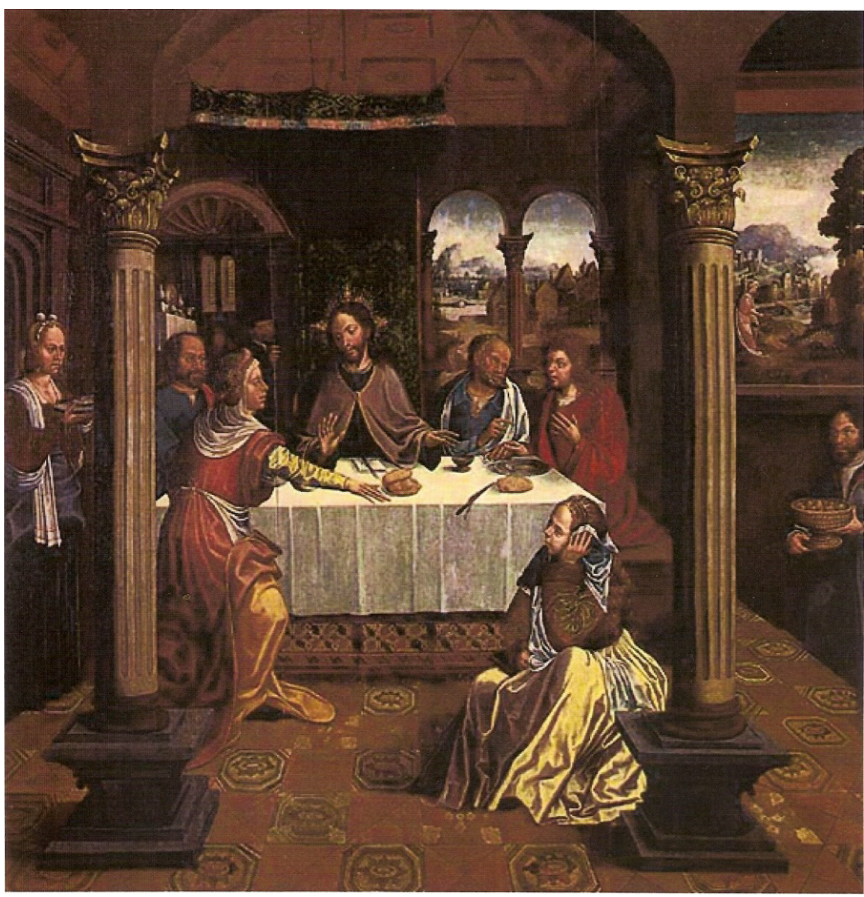

exemplo, a compilação de receitas de Francisco Borges Henriques (17151729) foi reveladora da existência de uma significativa bateria de cozinha. Além de forno, fogão e fogareiro, contam-se agulhas de colchões, alfinetes, alguidares, almofarizes, azados, bacias, bacias vidradas, batedores, boiões, boiões vidrados, cafeteiras, canivetes, carretilhas, cestos, xícaras, chocolateiras, colherões, colheres, colheres de prata, colheres de ferro, covilhetes, cutelos, escumadeiras, espetos, facas, farpinhas agudas de dois gumes, frigideiras, frigideiras vidradas, funis, garrafas, garfos, grais, guardanapos, joeiras, linhas, moinhos, palanganas, palhas de junco, panelas, panelinhas, panelinhas vidradas, palhinhas, panos, papéis diversos, paus de estender, 

FIGURA 4 - GREGÓRIO LOPES - SALOMÉ APRESENTANDO A CABEÇA DE SÃO JOÃO BAPTISTA A HERODES. CERCA DE 1538-1539. TOMAR, IGREJA DE SÃO JOÃO BAPTISTA.

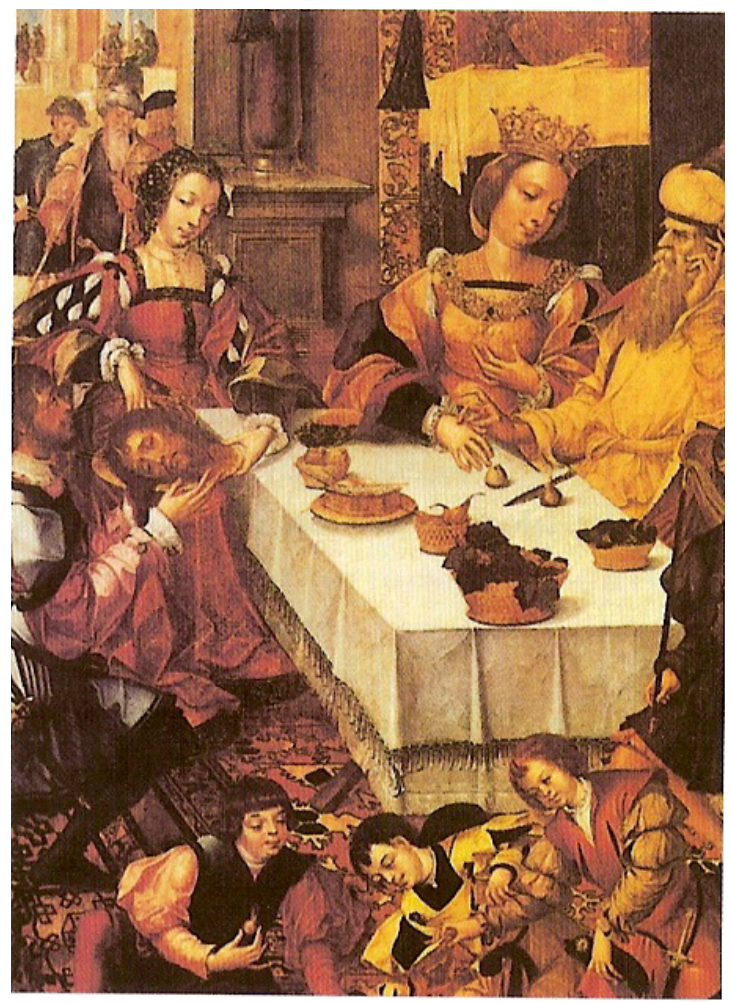

peneiros, pincéis, pratos, pratos de prata, prensas, púcaros, ralos (raladores), rengos, tábuas, tabuleiros, taças, tachos, tenores, tigelas, torteiras, vasilhas e vasos vidrados ${ }^{32}$.

Se tivermos em conta a bateria de cozinha referenciada na Arte nova e curiosa (1778), primeira obra integralmente dedicada à doçaria,

32 BRAGA, Isabel M. R. Mendes Drumond. O livro de cozinha de Francisco Borges Henriques. Do primeiro almoço à ceia. Estudos de História da Alimentação. Sintra: Colares Editora, 2004, p. 78. 
FIGURA 5 - EXCERTO DE UM FÓLIO DO LIVRO DE RECEITAS DE FRANCISCO BORGES HENRIQUES.

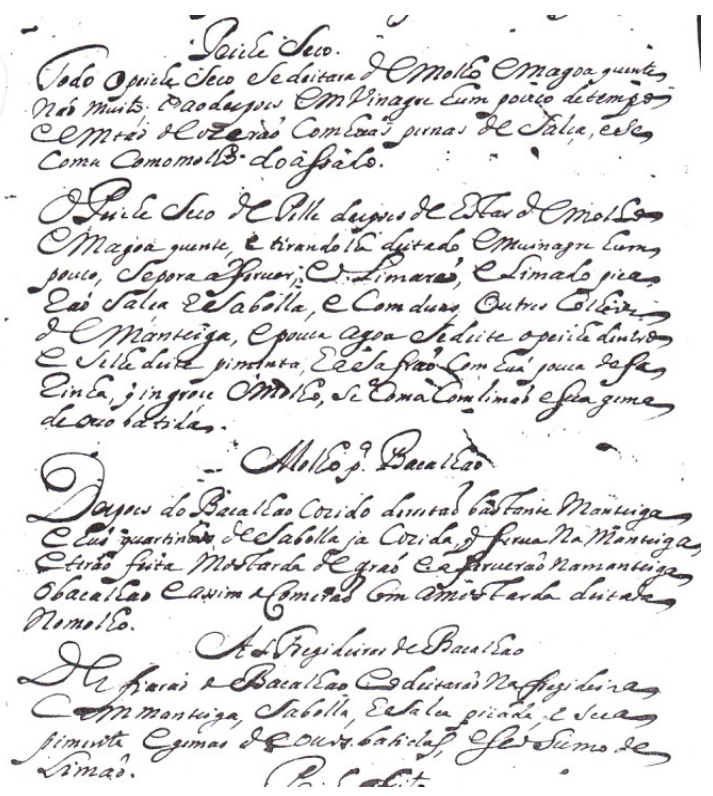

podemos encontrar, além de um forno e de um fogão, alfinetes, alguidares, alguidares vidrados, almofarizes, atanores (espécie de vasos), bacias de fartéis, bandejas, bandejas vidradas, balanças, caçoulas (caçarolas), caixas, caixas de vidro, caninhas, cantimploras (vasos ou bilhas para esfriar bebidas), canivetes, canudos (rolos da massa), carretilhas, chavões (moldes ou marcas), colheres, copos, infusas (bilhas de barro com bico), escudelas, escumadeiras, facas, frigideiras, furadores, garfos, grais, joeiras, lençóis, luvas, palanganas (tabuleiros de forno ou tigelas grande para caldo), palanganas de barro vidrado, peneiras de rala, panelas, panelas vidradas, panos, panos ralos, redomas, panos de linho, papéis, penas (para pincelar), peneiras de seda, porsolanas (tigelas), pratos de prata, púcaros, púcaros com buraco (tipo funil para fios de ovos), redomas, sopeiras vidradas, sorveteiras, tábuas, tabuleiros, tachos, tachos de cobre, tesouras, tigelas de caldo com pé, 
tigelinhas, tinores (vasilhas de barro onde se guardava o mel, ou pote grande com duas asas), vasilhas, vasilhas de vidro e vasos vidrados ${ }^{33}$.

\section{FIGURA 6 - FRONTISPÍCIO DO PRIMEIRO LIVRO DE DOÇARIA IMPRESSO EM PORTUGAL.}

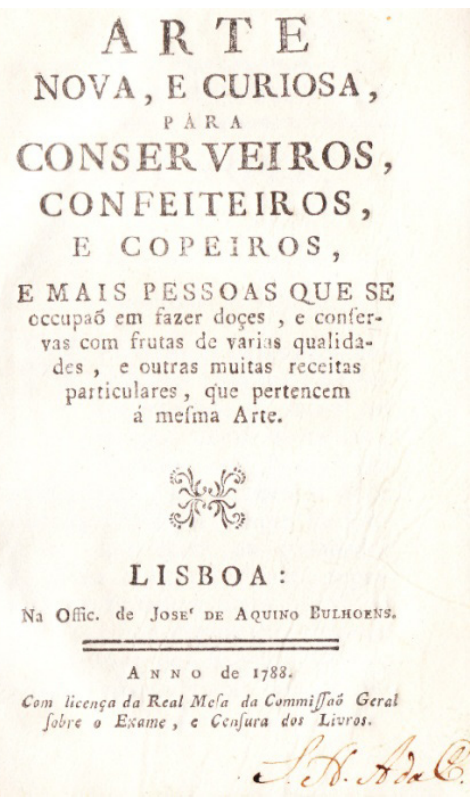

Nos séculos XVII e XVIII, os inventários de bens de pessoas processadas pelo Santo Ofício evidenciam as possibilidades deste tipo de fontes, mormente a reconhecida importância e riqueza informativa para o estudo do entesouramento, do luxo, do coleccionismo, dos níveis de vida e dos padrões de consumo na Época Moderna, perscrutados pela posse de escravos e de bens de luxo - peças de vestuário e de adorno, nomeadamente joias; mobiliário e outro recheio da casa, como objectos de cozinha, roupa de cama e de mesa,

33 BRAGA, Isabel M. R. Mendes Drumond. O primeiro livro de doçaria portuguesa (1788). Arte nova e curiosa para conserveiros, e copeiros e mais pessoas que se ocupam em fazer doces e conservas com frutas de várias qualidades e outras muitas receitas particulares da mesma arte. Estudo e actualização do texto de Isabel M. R. Mendes Drumond Braga. Sintra: Colares, 2004, p. 17. 
pratas, alfaias litúrgicas, livros, instrumentos musicais, diversos objectos de colecção, carruagens e outros. Efectivamente, os inventários de gente abastada permitem, inclusivamente, perceber a introdução de novos objectos no património familiar e a presença de peças de vários espaços ultramarinos, como, por exemplo, mobiliário confeccionado com madeiras exóticas asiáticas e brasileiras, joias de ouro e gemas, em especial durante o século XVIII, mas com antecedentes claros ainda na centúria anterior ${ }^{34}$. De qualquer modo, os inventários são, regra geral, parcos na descrição de objectos de cozinha ${ }^{35}$. O reduzido valor dos mesmos, em especial no que se refere aos de madeira e barro, e o facto de tachos e panelas serem assuntos femininos, explica estas ausências, particularmente visíveis nos depoimentos masculinos. Os objectos de metal não nobre, as porcelanas e as pratas constituíram uma excepção. Não obstante, para os séculos XVII e XVIII restam-nos diversos depoimentos de homens e de mulheres, como os que se seguem ${ }^{36}$. Ana de Munhoz referiu alguidares, bacias, um caldeirão de cobre, cântaros, escumadeiras, palanganas, uma panela, uma poma de vidro, tabuleiros da China, tachos de arame, talhas e ainda almofarizes de pisar amêndoas ${ }^{37}$. Esta mesma referiu a posse de peças de porcelana, as quais começaram a chegar a Portugal logo após a primeira viagem de Vasco da Gama ${ }^{38}$. Efectivamente, Ana de Munhoz fora casada com Francisco de Milão, "que fazia viagens a Índia”, e no seu inventário explicitou a posse de louça da Índia e da terra num armário e de porcelanas da Índia pertencentes a sua irmã, dentro de um mafamede ${ }^{39}$. Isa-

34 BRAGA, Isabel M. R. Mendes Drumond. O vestuário e a Casa dos Mercadores Portugueses seiscentistas: simplicidade ou luxo? Semata. Ciéncias Sociais e Humanidades, Santiago de Compostela, v. 21, p. 141-165, 2009.

35 Sobre a bateria de cozinha, cf. BRAGA, Isabel M. R. Mendes Drumond. Alimentação, etiqueta e sociabilidade em Portugal no século XVIII. Cultura, religião e quotidiano. Portugal (século XVIII). Lisboa: Hugin, 2005, p. 165-231; Idem. Do primeiro almoço à ceia. Estudos de História da Alimentação. Sintra: Colares Editora, 2004.

36 Temos em curso um projecto de investigação sobre os inventários de bens dos indivíduos processados pelo Santo Ofício ao longo dos séculos XVII e XVIII. Os exemplos que se seguem aparecem a título ilustrativo sem qualquer preocupação quantitativa.

37 Lisboa, Arquivos Nacionais Torre do Tombo (A.N.T.T.). Inquisição de Lisboa, proc. 4003.

38 BUARCOS, João Brandão de. Grandeza e abastança de Lisboa em 1552. Organização e notas de José da Felicidade Alves. Lisboa: Livros Horizonte, 1990, p. 60; HERCULANO, Alexandre. Viagem a Portugal dos Cavaleiros Tron e Lippomani (1580). Opúsculos, v. 4. Organização, introdução e notas de Jorge Custódio e José Manuel Garcia. Lisboa: Presença, 1985, p. 366; DIAS, Pedro.Símbolos e imagens do Cristianismo na porcelana chinesa. Reflexos. Catálogo. Lisboa: Misericórdia de Lisboa, Comissão Nacional para as Comemorações dos Descobrimentos Portugueses, 1996, p. 17-59.

39 Lisboa, A.N.T.T. Inquisição de Lisboa, proc. 4003. 
bel Soares arrolou quatro pratos da Índia pequenos, uma canastra de louça, um tacho de cobre grande, um cesto e "outras miudezas necessarias para o uso de sua casa", além de duas colheres de prata ${ }^{40}$; D. Branca da Gama e Figueiró informou possuir "bastante arame na sua cozinha e entre este duas quartas grandes de cobre, duas panelas do mesmo, um fogareiro de cobre grande e outros tachos", além de uma fonte de arame com uma bacia e um braseiro grande de Hamburgo ${ }^{41}$, enquanto João e Ávila arrolou um almofariz, uma caldeira e um tacho de cobre, duas cestas, dois espetos e uma trempe ${ }^{42}$. Depoimentos do século XVIII eram afins. Por exemplo, Mariana da Fonseca deu conta da posse de um serviço de estanho com pratos e tigelas e "mais trastes de casa e serviço de cobre e latão de cozinha de que não estava muito presente" "43; Francisco Gabriel Ferreira indicou um talher de estanho usado, três tachos de cobre, um dos quais pequeno e duas chocolateiras ${ }^{44}$; Francisco da Costa Salgado arrolou dois tachos de arame, uma bacia de farteis, uma sertã, uma outra bacia, uma panela de cobre ${ }^{45}$, enquanto António Ribeiro Sanches indicou meia dúzia de pratos de guardanapo de estanho, dois outros pratos grandes de meia cozinha e dois tachos de cobre (um grande outro pequeno), tudo avaliado em cerca de 10.000 réis $^{46}$.

O luxo da casa também se avalia tendo em conta outros objectos. Vejamos o caso das pratas ${ }^{47}$. A maioria dos mercadores ou de viúvas de mercadores processados durante o século XVII, que foram objecto de inventário, deu conta de alguma peça do metal branco entre os seus bens ligados ao serviço dos alimentos. De qualquer modo, o património argen-

40 Lisboa, A.N.T.T. Inquisição de Évora, proc. 8325.

41 Lisboa, A.N.T.T. Inquisição de Lisboa, proc. 940.

42 Lisboa, A.N.T.T. Inquisição de Lisboa, proc. 903.

43 Lisboa, A.N.T.T. Inquisição de Coimbra, proc. 9079.

44 Lisboa, A.N.T.T. Inquisição de Coimbra, proc. 9699.

45 Lisboa, A.N.T.T. Inquisição de Évora, proc. 2233.

46 Lisboa, A.N.T.T. Inquisição de Lisboa, proc. 11603.

47 Sobre as pratas do período moderno, cf. VASCONCELOS E SOUSA, Gonçalo de. Elementos para a História da Ourivesaria no Porto no século XVIII. Poligrafia, Porto, n. 5, p. 95-102, 1996; Idem. A joalharia em Portugal: 1750-1825. Porto: Civilização, 1999; Idem. Objectos preciosos e representação das elites da Corte Portuguesa de setecentos. Armas e Troféus. Revista de História, Heráldica, Genealogia e Arte, Lisboa, 9. série, p. 229-252, 2002-2003; Idem. A ourivesaria da prata em Portugal e os mestres portuenses. História e sociabilidade (1750-1810). Porto: Edição do Autor, 2004; Idem. Ouro, prata e outras riquezas setecentistas numa herança da Bahia (Brasil). Revista da Faculdade de Letras. Ciências e Técnicas do Património, Porto, 1. série, v. 3, p. 293-316, 2004; Idem. Pratas e joias dos $1 .^{\text {os }}$ Barões de Ancede. $O$ Tripeiro, Porto, 7. série, n. 1, p. 10-13, 2004. 
tário declarado pela maior parte dos réus não era muito avultado ${ }^{48}$. Se Ana de Munhoz apenas declarou seis colheres e dois garfos, duas "bocetinhas", uma tambuladeira e um púcaro ${ }^{49}$, António Dias Arias também não arrolou grande valor em prataria: uma salva, um púcaro e dois copos com pires ${ }^{50}$. Situação semelhante aconteceu com António Mendes, dono de uma salva, um copo e seis colheres ${ }^{51}$ ou com Henrique Rodrigues Lopes, possuidor de um púcaro e de uma salva ${ }^{52}$. Já Catarina Rodrigues referiu um copo com prato e umas galhetas com prata ${ }^{53}$. Alguma diversidade verifica-se igualmente no inventário de Francisco Vaz de Leão: uma salva, um saleiro, 12 garfos e colheres e duas facas com cabos de prata, tudo avaliado em 11 ou 12.000 réis $^{54}$; no de Gaspar Vaz de Sequeira: 12 ou 13 colheres, seis garfos, duas facas com cabo de prata, uma palangana, duas salvas e dois pires ${ }^{55} \mathrm{e}$ no de Manuel da Silveira, que era dono de quatro facas de cabos de prata, um pratinho e um copo (5.000 réis) e três copos dourados "que estão huns nos outros" (5 ou 6.000 réis) ${ }^{56}$. Menos rico era o património argentário de Diogo de Chaves: uma salva, dois copos, dois pires, algumas colheres, garfos e facas com cabo de prata $^{57}$; de Duarte Moreno Nunes: uma salva grande outra pequena, um púcaro e seis colheres ${ }^{58}$; de Henrique Pit: um jarro, um saleiro e dois pratos ${ }^{59}$ ou de Rafael Rodrigues Lopes: um copo de algibeira e algumas colheres ${ }^{60}$. De idêntico teor eram os bens de Jerónima Gomes: um jarro, um saleiro e um púcaro ${ }^{61}$; de João de Leão: um copo, um púcaro, uma salva de galhetas, uma taça e quatro ou cinco colheres ${ }^{62}$; de Manuel Rodrigues Preto: um copo, três ou quatro colheres, dois garfos, uma ou

48 Para Jacques Sobieski, um polaco que visitou Lisboa, no princípio do século XVII, alguns mercadores portugueses tinham tapeçarias e pratas em abundância. Cf. ZUILI, MARK. Un polonais en Espagne et au Portugal au début du XVII siècle: Jacques Sobieski. Da Est ad Ouest, da Ouest ad Est. Viaggiatori per le strade del mondo. Direcção de Gaetano Platania. Viterbo: Sette Città, 2006, p. 47-48.

49 Lisboa, A.N.T.T. Inquisição de Lisboa, proc. 6003.

50 Lisboa, A.N.T.T. Inquisição de Lisboa, proc. 11385.

51 Lisboa, A.N.T.T. Inquisição de Lisboa, proc. 13016.

52 Lisboa, A.N.T.T. Inquisição de Lisboa, proc. 10649.

53 Lisboa, A.N.T.T. Inquisição de Lisboa, proc. 11763.

54 Lisboa, A.N.T.T. Inquisição de Lisboa, proc. 9216.

55 Lisboa, A.N.T.T. Inquisição de Lisboa, proc. 11299.

56 Lisboa, A.N.T.T. Inquisição de Lisboa, proc. 9472.

57 Lisboa, A.N.T.T. Inquisição de Lisboa, proc. 4426.

58 Lisboa, A.N.T.T. Inquisição de Lisboa, proc. 9212.

59 Lisboa, A.N.T.T. Inquisição de Lisboa, proc. 12387.

60 Lisboa, A.N.T.T. Inquisição de Lisboa, proc. 9952.

61 Lisboa, A.N.T.T. Inquisição de Lisboa, proc. 10220.

62 Lisboa, A.N.T.T. Inquisição de Lisboa, proc. 9719. 
duas facas com cabo de prata e uma tambuladeira avaliada em 25 ou 26 tostões $^{63}$ e de Manuel Soares: um saleiro, uma salva, umas 12 colheres e quatro garfos ${ }^{64}$. No século XVIII, a situação era semelhante, entre mercadores e suas famílias ou entre pessoas de outras actividades. Por exemplo, Mariana da Fonseca arrolou seis pratos, três bandejas, duas galhetas, duas tigelas, um jarro, um saleiro, uma colherzinha, seis facas, seis colheres e seis garfos ${ }^{65}$. Em síntese, note-se, sobretudo, a presença de talheres, copos, púcaros e salvas e mais raramente de outras peças.

No Brasil a situação era afim, se observarmos inventários de bens de mulheres residentes no Rio de Janeiro no início do século XVIII, aparentadas com senhores de engenhos e com mercadores ${ }^{66}$, verificaremos que a prataria está parcamente presente. Nomeadamente, três colheres de D. Brites da Costa $^{67}$, uma salva grande, um coco, seis colheres e três facas que integravam o património de D. Esperança de Azevedo ${ }^{68}$, e um púcaro, duas salvas, uma caixa e uma tambuladeira, pertencentes a Maria Henriques ${ }^{69}$. Mais rico era o património argentário de $\mathrm{D}$. Brites de Paredes: um jarro, um prato de água às mãos, uma bacia de barbear, duas salvas, três pratos de meia covinha, 18 pratos ordinários, 18 colheres, seis garfos e uma tambuladeira ${ }^{70}$. Menos representatividade tiveram as porcelanas. Apenas D. Guiomar de Azevedo referiu possuir alguma louça da Índia, no valor de 40.000 réis $^{71}$. Alguns dos inventários em estudo foram, contudo, ricos em informações acerca do recheio das cozinhas ${ }^{72}$, matéria normalmente ausente nos inventários masculinos dos residentes na colónia. Assim, entre os utensílios utilizados para a guarda dos alimentos, contam-se caixas e caixões, enquanto para

63 Lisboa, A.N.T.T. Inquisição de Lisboa, proc. 10228.

64 Lisboa, A.N.T.T. Inquisição de Lisboa, proc. 10384.

65 Lisboa, A.N.T.T. Inquisição de Coimbra, proc. 9079.

66 BRAGA, Isabel M. R. Mendes Drumond. Patrimónios femininos no Rio de Janeiro setecentista. Revista de la Inquisición, no prelo.

67 Lisboa, A.N.T.T. Inquisição de Lisboa, proc. 10145.

68 Lisboa, A.N.T.T. Inquisição de Lisboa, proc. 10167.

69 Lisboa, A.N.T.T. Inquisição de Lisboa, proc. 11785.

70 Lisboa, A.N.T.T. Inquisição de Lisboa, proc. 973.

71 Lisboa, A.N.T.T. Inquisição de Lisboa, proc. 10244.

72 Sobre as cozinhas brasileiras, cf. LEMOS, Carlos A. C. Cozinhas etc. Um estudo sobre as zonas de serviço da casa paulista. São Paulo: Perspectiva, [s.d.]. Sobre os utensílios de cozinha, cf. ALGRANTI, Leila Mézan. Famílias e vida doméstica. História da vida privada no Brasil. Cotidiano e vida privada na América Portuguesa, v. 1, Coordenação geral de Fernando A. Novais, organização do volume de Laura de Mello e Sousa. São Paulo: Companhia das Letras, 1997, p. 118-126. 
a preparação das refeições foram arrolados diversos objectos. Catarina Gomes referiu um talher de estanho de cinco peças, além de dois tachos, um grande e outro pequeno ${ }^{73}$. D. Esperança de Azevedo deu conta de seis bacias de arame, um graal de pedra, duas dúzias de pratos de estanho, além de balanças de arame de pesar doces e de um fogareiro grande de cobre, no valor de 12.000 réis, o que estava directamente relacionado com a sua actividade profissional ${ }^{74}$. Por seu lado, Maria Henriques disse ser dona de quatro tachos de cobre, um dos quais tinha na cidade e os restantes na roça ${ }^{75}$.

Nos banquetes e nas refeições dos mais abastados a mesa era posta com serviços de porcelana oriental ou europeia, vidros ${ }^{76}$ e peças diversas de prata, nacionais ou importadas, incluindo, naturalmente, os talheres ${ }^{77}$. Era frequente a porcelana brasonada de produção asiática. Menos requintado era o uso de faianças nacionais ou estrangeiras. No que se refere à posse de serviços de porcelana europeia, sabe-se, por exemplo, que o marquês de Penalva, no final do século XVIII, mandou servir um pequeno almoço em porcelana de Dresden ${ }^{78}$. Além da porcelana havia a faiança, de menor beleza e de desgaste mais rápido. Podia ser de produção nacional ou estrangeira, neste caso com destaque especial para a oriental e para a inglesa. De qualquer modo, a qualidade, a duração e o preço não eram semelhantes aos das porcelanas.

As peças de prata também podiam ser realizadas em Portugal ou importadas. Por exemplo, em 1753, D. José António Francisco Lobo da Silveira Quaresma (1698-1773), $10 .^{\circ}$ barão e primeiro marquês de Alvito e terceiro conde de Oriola, mandou adquirir em Londres, através do seu representante, diversos objectos para a mesa. A conta, liquidada em 1760, foi na ordem das 48219,10 £ ou $1.972 \$ 840$ réis. Neste quantitativo, compreendeu-se o gasto com as peças, o seguro (500£) e a comissão ( $2 \frac{1}{2} \%$ ). A lista das peças de prata e outros materiais compreendeu: oito salvas, uma caldeira, duas

\footnotetext{
77 VASCONCELOS E SOUSA, Gonçalo de. Pratas portuguesas em colecções particulares: século XV ao século XX. Porto: Civilização, 1998, p. 24-28 e inventário de peças, especialmente p. 188223.

78 SANTOS, Piedade Braga; RODRIGUES, Teresa; NOGUEIRA, Margarida Sá. Lisboa setecentista vista por estrangeiro. Lisboa: Livros Horizonte, 1987, p. 57.
} calense, 1950 .

Lisboa, A.N.T.T. Inquisição de Lisboa, proc. 10242.

Lisboa, A.N.T.T. Inquisição de Lisboa, proc. 10167.

Lisboa, A.N.T.T. Inquisição de Lisboa, proc. 11785.

6 Vejam-se exemplos de vidros in: VALENTE, Vasco. O vidro em Portugal. Porto: Portu- 
cafeteiras, dois bules, dois bicos de "aquentar" os pratos, dois manteigueiros, dois mostardeiros, dois açucareiros, mais um outro com tampa; dois potes para leite, quatro saleiros, um tigela para lavar as xícaras, um espevitador com prato, uma colher para punch, um assobio, quatro dúzias de colheres e quatro dúzias de garfos, duas dúzias de talheres ( $\mathrm{sic}$ ), duas dúzias de garfos para sobremesa, quatro dúzias de cabos de facas, duas dúzias de facas com ferros de prata, duas colheres de sopa e quatro mais pequenas, duas dúzias de colheres para chá, duas escumadeiras, duas tenazes, duas colheres para mostarda e duas para os saleiros, dois cabos de pau para as cafeteiras, duas caçarolas de cobre para os bicos de aquecer os pratos, oito vidros para os saleiros e quatro para os mostardeiros, seis galhetas de vidro cortado com tampas de prata, seis faqueiros de lixa, dois estojos para as colheres de chá, uma caixa e um caixão ${ }^{79}$.

4. Quando chegamos ao século XIX, o manancial de utensílios era já bastante vasto, recorrendo-se, entre outros, a tigelas, panelas, tachos, caços ou caçarolas, formas ou latas e tabuleiros para levar os ingredientes ao lume; a viradouros e frigideiras no caso dos géneros que eram fritos, podendo os referidos utensílios servir também para ir ao forno e à mesa. Para mexer e misturar alimentos, usavam-se bacias, as quais também iam ao lume, alguidares e vasos. Colheres, garfos, facas, escumadeiras, escalfadeiras, estendedores, peneiras, rapadouras, funis, covilhetes, almoxarifes, graais, salseiros, chocolateiras, açucareiros, molheiras, pratos, pires, sopeiras, travessas, terrinas, copos, chávenas, canecas, fruteiros, cestos e jarros completavam o quadro dos utensílios que serviam para preparar e apresentar os alimentos ${ }^{80}$. Timidamente, foram aparecendo alguns instrumentos mais sofisticados, como, por exemplo, moinhos de café, assadores de ferro para castanhas e máquinas de ralar batatas ${ }^{81}$.

Com base em documentação de uma casa nobre, a dos barões de Arruda, Gonçalo de Vasconcelos e Sousa pôde estudar certa "herança do Brasil”, concretamente de engenhos do recôncavo da Bahia, recebida no

79 Alvito, Arquivo Particular. Casa de Alvito, pasta 3, doc. não numerado. Agradecemos à Senhora Arquitecta Maria Antónia Goes a sua consulta.

80 FERRO, João Pedro. Arqueologia dos hábitos alimentares. Lisboa: Dom Quixote, 1996, p. 16.

81 O Gratis. Jornal de Annuncios e do Commercio. Lisboa, n. 1941, de 19 de fevereiro de $1846 ;$ n. 1999 , de 18 de maio de 1846. 
FIGURA 7 - PAINEL DE AZULEJOS DO SÉCULO XVIII, ONDE SE PODE OBSERVAR O DECURSO DE UMA REFEIÇÃO E UM REFRESCADOR DE GARRAFAS. LISBOA, PALÁCIO DOS GUIÕES.

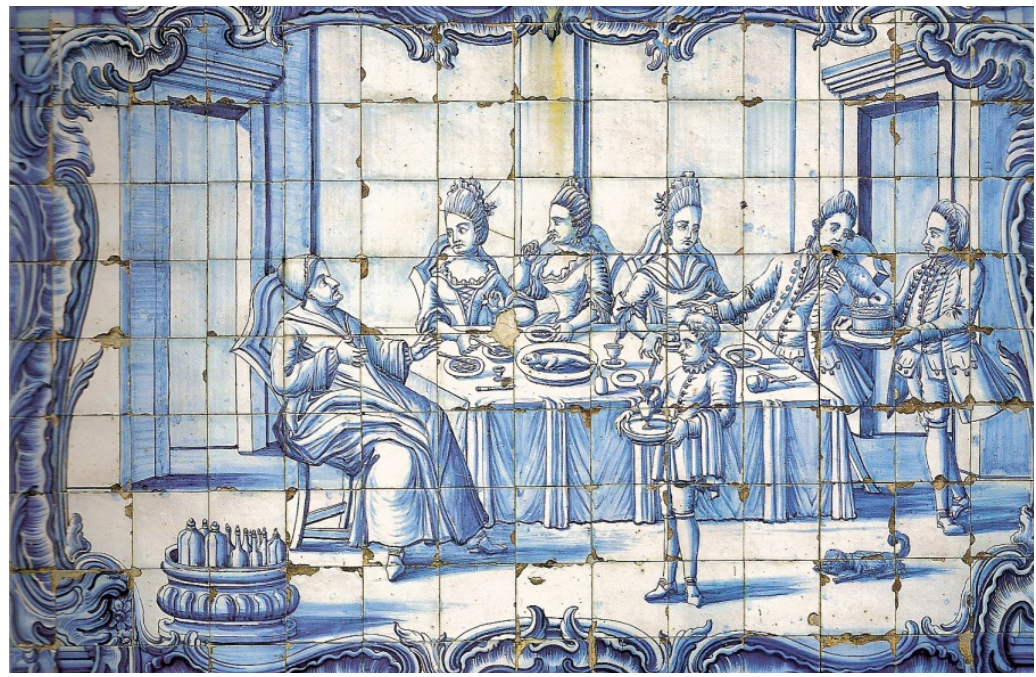

início do século XIX por D. Ana Rosa da Silva, casada com o desembargador Domingos de Gamboa e Liz, sogros do primeiro barão de Arruda. Entre os bens móveis que integraram a herança que ficou por morte de José Álvares da Silva e de D. Águeda Maria do Sacramento, contam-se diversos objectos de mesa de prata, de porcelana e de louça inglesa, os quais demonstram certos requintes à mesa. Assim, pelos inventários, tomamos conhecimento de: um fruteiro, três salvas e diversos talheres de prata, além de serpentinas e castiçais para iluminação; porcelanas orientais, denominadas "louça da Índia": terrinas, pratos, saladeiras, mostardeiras, saleiros, xícaras de chá, de chocolate e de café, bules, leiteiras e açucareiros, além de diversas peças de louça inglesa e de louça de pó de pedra ${ }^{82}$.

Inventários de bens de outras localidades merecem igualmente atenção. Por exemplo, o do negociante mineiro António Francisco Rego

82 VASCONCELOS E SOUSA, Gonçalo de. Ouro, prata e outras riquezas setecentistas [...], p. $293-316$. 
Arantes, falecido em 1821, refere nove pratos de guardanapo, seis pratos menores e cinco maiores, todos de pó de pedra; seis xícaras com pires, três meias tigelas, uma caneca de louça do Porto e outra de louça inglesa e alguns talheres de prata: sete facas, sete colheres, sete garfos, uma colher grande e quatro de chá ${ }^{83}$. Sónia Maria de Magalhães estudou cerca de 300 inventários, datados de 1750 a $1850,87,5 \%$ de homens e $12,5 \%$ de mulheres, podendo comprovar que apenas 24 do século XVIII e 16 do século XIX revelaram a posse de objectos nobres de mesa. Em seis há referência a louça do Porto (todos do século XIX), em 16 a louça das Índias (seis do século XIX) e em 26 a talheres de prata e outros utensílios de mesa (10 do século XIX) ${ }^{84}$. Por seu lado, entre o recheio da casa da baronesa de Goitacazes, situada na Glória (Rio de Janeiro), encontravam-se porcelanas chinesas, colchas da Índia, espelhos e caixas de charão da China, a par de joias e escravos ${ }^{85}$. Em São Paulo, a realidade não era diferente. Os inventários de bens dão conta de, entre os objectos de mesa, prataria, louça do Porto, da Índia, Macau, Veneza, da terra e de estanho, a par de serviços ingleses e peças para a cozinha como boiões e panelas de louça vidrada da Bahia, copos e cálices de vidro, panelas e tachos de ferro e de cobre ${ }^{86}$.

À medida que se descia na pirâmide social, era visível uma diminuição, até a ausência, da maioria dos objectos que estavam presentes na mesa dos grupos privilegiados. Se este era o quadro vigente no Reino, não muito diferente era no Brasil colonial. Em qualquer espaço, a etiqueta à mesa variava com os grupos sociais. Na Gazeta de Lisboa podem encontrar-se anúncios de vários utensílios de mesa. Por exemplo, leiloavam-se partidas de louça oriental num armazém da rua Nova do Almada ${ }^{87}$, serviços de

83 MAgAlHãeS, Sónia Maria de. A mesa de Mariana. Produção e consumo de alimentos em Minas Gerais (1750-1850). São Paulo: Annablume, p. 117.

84 MAGALHÃES, Sónia Maria de. A mesa de Mariana [...], p. 118-119. Sobre objectos de mesa nos inventários, cf. também MALERBA, Jurandir. A Corte no exílio. Civilização e poder no Brasil às vésperas da Independência (1808-1821). São Paulo: Companhia das Letras, 2000, p. 160-162.

85 CUNHA, Rui Vieira da. A vida do Rio de Janeiro através dos testamentos: 1815-1822. Revista do Instituto Histórico e Geográfico Brasileiro, Rio de Janeiro, v. 282, p. 60, 1969. Sobre o Rio de Janeiro, cf. também LIMA, Tania Andrade. Pratos e mais pratos: louças domésticas, divisões culturais e limites sociais no Rio de Janeiro, século XIX. Anais do Museu Paulista, São Paulo, nova série, n. 3, p. 129-191, 1995.

86 ARAÚJO, Maria Lucília Viveiros. Os interiores domésticos após a expansão da economia exportadora paulista. Anais do Museu Paulista, São Paulo, nova série, v. 12, p. 129-160, 2004.

87 Gazeta de Lisboa, n. 57, de 8 de março de 1814. 
mesa, prataria, vidros e louça na casa de pasto Latour, no Cais do Sodré88, partidas de porcelana dourada, louça da Índia, de casquinha com guarnições de prata, vidros e cristais, no Corpo Santo ${ }^{89}$ e um plateau, terrinas, pratos, bandejas e outras peças de prata, no largo do Caldas ${ }^{90}$. Na rua do Alecrim, vendiam-se "toalhas de mesa adamascadas de padrões elegantes e novos com seus guardanapos competentes" ${ }^{\prime 91}$. No Brasil, as populações do litoral, mais habituadas aos contactos com o exterior e aos estrangeiros, estavam mais próximas dos hábitos europeus; o mesmo não se passava no interior, em que o desconhecimento dos mais comuns utensílios de mesa era vulgar. Efectivamente, no Rio de Janeiro podiam adquirir-se baixelas de prata, cristais e louças francesas em segunda mão, vendidas por particulares ${ }^{92}$, em simultâneo com as ofertas dos estabelecimentos especializados, como a de um armazém da rua da Alfândega, que vendia "grande porção de cristais para serviço de mesa e dessert, assim como aparelhos para mesa e chá, ingleses e da China, dos melhores gostos [...], louça branca e pintada em gigas e grande sortimento de louça preta de novos padrões" ${ }^{\prime 93}$ ou, em novo anúncio, "louça da China para chá e mesa tanto esmaltada como de porcelana e ouro, toda a qualidade de cristais, vidros, painéis, espelhos e louça de Chinchen a preços cómodos"94. Outros estabelecimentos também vendiam produtos afins. Carlos Durand, negociante francês, estabelecido na rua do Ouvidor, tinha à disposição dos clientes vinhos franceses, roupa de mesa adamascada ${ }^{95}$ e pratas de mesa ${ }^{96}$, especificando-as em 1819: açucareiros, bules, cafeteiras, galhetas, saleiros e talheres ${ }^{97}$. Joaquim José Pereira de Faro, com estabelecimento na rua dos Pescadores, disponibilizava aparelhos de chá, xícaras finas, toalhas de mesa e guardanapos, segundo um anúncio ${ }^{98}$, e porcelanas de mesa, francesas e chinesas, segundo outro ${ }^{99}$. Isto é, em Portugal ou no

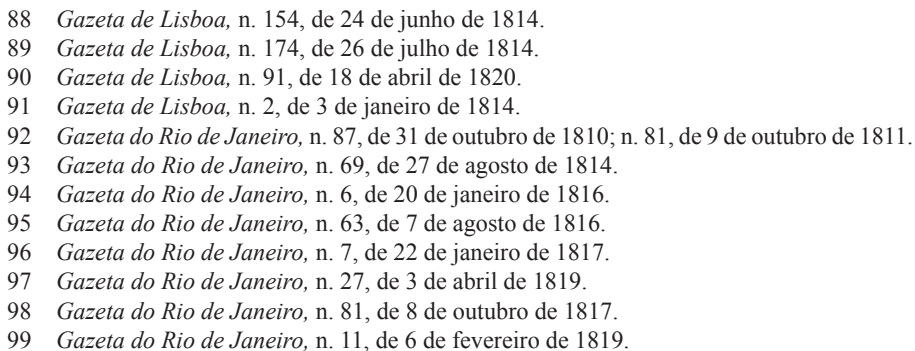


Brasil colónia, as refeições dos abastados desenvolviam-se num quadro com um ritual próprio, no qual contavam as tradições familiares e o acesso às novidades estrangeiras, nomeadamente francesas e inglesas. Nada ficava ao acaso, desde o modo de dispor a baixela, decorar a mesa, distribuir os lugares, dispor as iguarias e desenvolver o serviço à mesa pelos criados. A mesa era posta com serviços de porcelana, cristais e vidros moldados, lapidados e gravados ${ }^{100}$ e peças diversas de prata, incluindo os talheres ${ }^{101}$.

Entre as peças de porcelana, saliente-se as brasonadas de produção europeia e asiática, neste caso com destaque para a da Companhia das Índias. As porcelanas podiam ser de produção estrangeira, nomeadamente inglesa ${ }^{102}$ e da Companhia das Índias, bem como de produção nacional, sendo a de melhor qualidade a que era produzida na fábrica da Vista Alegre, a partir de 1835, não obstante os esforços anteriores, levados a cabo a partir de $1824^{103}$. De notar ainda um certo gosto pelo exótico, traduzido na utilização de peças orientais ou de influência oriental, uma boa parte das

100 Vejam-se exemplos de vidros lapidados e gravados (copos e jarros) in: VALENTE, Vasco. O vidro em Portugal. Porto: Portucalense, 1950, gravuras entre as p. 76 e 77; D. João VI e o seu tempo. Exposição. Lisboa: Comissão Nacional para as Comemorações dos Descobrimentos Portugueses, 1999 , p. 203, 206 e de vidros e cristais lapidados e moldados, alguns com camafeus incrustados in: Vista Alegre. Porcelanas. Lisboa: Inapa, 1989, p. 63-69; I Leilão Vista Alegre. Lisboa: As Coisas Mudam, 1997, lotes 1 a 18; II Leilão Vista Alegre. Cristais, vidros, porcelanas e biscuits. Lisboa: Estar, 1998, p. 13-20; III Leilão Vista Alegre. Cristais, vidros, porcelanas e biscuits. Lisboa: Estar, 1999, p. 13-22. Entre as peças contam-se compoteiras, copos, fruteiros, galheteiros, garrafas, jarros, mamadeiras, pratos e taças.

101 As peças de prata produzidas neste período foram fundamentalmente de influência neoclássica e mais tenuamente do estilo império. Notou-se alguma simplicidade a par de decorações com motivos fitomórficos e zoomórficos. Entre a prataria utilizada à mesa contavam-se aparelhos de chá e café, alguns com tabuleiro; cafeteiras, candelabros, castiçais, cestos, espevitadeiras, faqueiros, galheteiros, jarros e bacias, samovares, suportes com lamparina de aquecimento e travessas. Cf. VASCONCELOS E SOUSA, Gonçalo de. Pratas portuguesas em colecções particulares: século XV ao século XX. Porto: Civilização, 1998, p. 24-28 e inventário de peças, especialmente p. 188-223.

102 BRAGA, Isabel M. R. Mendes Drumond. Portugal à mesa. Alimentação, etiqueta e sociabilidade (1800-1850). Lisboa: Hugin, 2000, p. 135-163.

103 Sobre a evolução da produção de loiça da fábrica, cf. as gravuras da obra Vista Alegre. Porcelanas. Lisboa, 1989, p. 73-78 e 81 a 106. Na fábrica, além das peças de vidro, produziram-se, pratos, cestos, galheteiros, açucareiros, molheiras, jarros, pires e chávenas em "pó de pedra" e, a partir de 1835, peças de porcelana perfeita, fabricadas com caulino, nomeadamente serviços de jantar e de chá, tête à tête com tabuleiros, jarros e bacias, floreiros, lamparinas, tinteiros, bases de candeeiros, jarras e frascos de rapé. Em 1826-1827, já foram realizadas chávenas e pires com sumptuosas decorações, nomeadamente a que em 1826 foi dedicada à infanta regente D. Isabel Maria. Sobre o contexto económico, industrial e artístico em que apareceu a fábrica, cf. MACEDO, Jorge Borges de. Introdução. Vista Alegre. Porcelanas [...], p. 11-33; AREZ, Ilda. Vista Alegre. Porcelanas Portuguesas. Prefácio de Rui Afonso Santos. Lisboa: Estar, 1998. Sobre a porcelana europeia deste período e nomeadamente de Sèvres, Limoges, Wedgwood, Worcester e 
quais de porcelana branca decorada a azul ${ }^{104}$. Além da porcelana, havia a faiança, de menor beleza e de desgaste mais rápido.

\section{FIGURA 8 - TAÇA COM PIRES. PORCELANA CHINESA DE ENCOMENDA, DINASTIA QING 1720-1740. \\ LISBOA, MUSEU NACIONAL DE ARTE ANTIGA.}

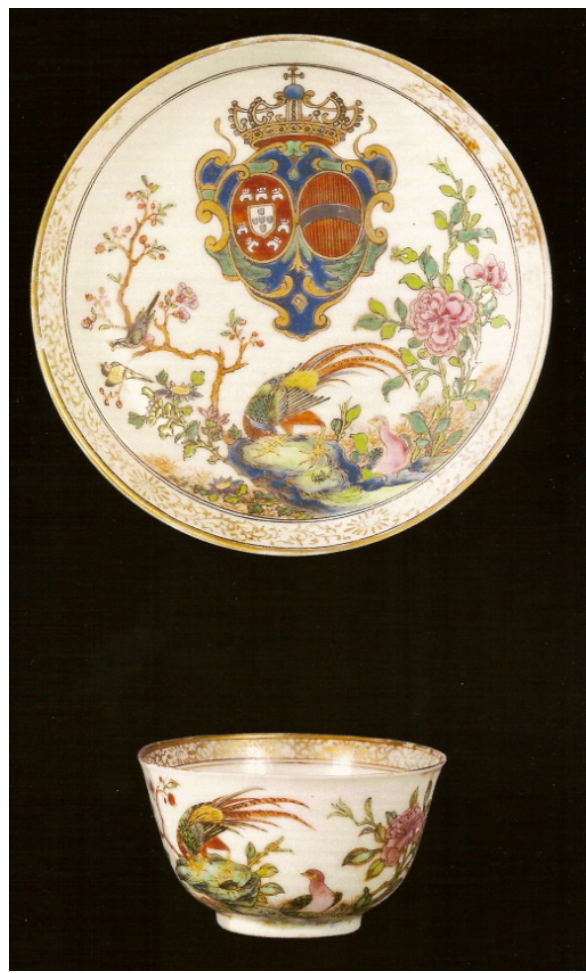

Chelsea, cf. BACCI, Mina. European Porcelain. Londres/Nova York/Sidney/Toronto: Hamlyn, 1966 e MORLEY-FLETCHER, Hugo. Investing in Pottery \& Porcelain. Londres: Barrie \& Rocklitt the Cressert Press, 1968.

104 GARNEL, Rita. O orientalismo no quotidiano. O orientalismo em Portugal - séculos XVI-XX. Lisboa: Comissão Nacional para as Comemorações dos Descobrimentos Portugueses, Inapa, Porto, Câmara Municipal, 1999, p. 285-313. 
De entre os que possuíam serviços da Companhia das Índias brasonados, da dinastia Qing, reinado Jiaqing (1796-1820), contam-se D. João VI (dois serviços diferentes, além de outras peças) ${ }^{105}$, D. António de São José de Castro, bispo e governador do Porto, e D. Duarte Manuel de Noronha Meneses, $4 .^{\circ}$ marquês de Tancos e $9 .^{\circ}$ conde de Atouguia ${ }^{106}$. Da mesma dinastia, reinado Daoguang (1821-1850), foram igualmente feitos diversos serviços para portugueses. Entre os seus possuidores, contaram-se D. Pedro I, imperador do Brasil, António de Albuquerque do Amaral Cardoso, conde dos Coutos; João Ferreira Sarmento, conde de Sarmento; Adrião Acácio da Silveira Pinto, governador de Macau e D. José Maria da Silva Torres, arcebispo de Goa ${ }^{107}$.

No que se refere à posse de serviços de porcelana europeia, sabe-se, por exemplo, que o duque de Palmela tinha um serviço de sobremesa inglês, o qual foi notado por Lichnowsky, ao escrever, em 1842, nas impressões acerca de Portugal: "a casa do duque está montada excelentemente, os seus jantares são delicadíssimos e a mesa curva-se sob o peso da prata; em uma formosa baixela de sobremesa, de porcelana inglesa, estavam representadas as suas armas com a legenda veritaten regibus" 108 . Os marqueses de Abrantes foram os primeiros titulares a encomendar um serviço de porcelana Vista Alegre, brasonado e decorado a ouro, o qual saiu da fábrica em $1846^{109}$. Posteriormente, outros nobres seguiram o exemplo ${ }^{110}$, tal como a própria Casa Real portuguesa.

A questão das louças teve repercussões em termos da indústria nacional, especialmente desde a segunda metade do século XVIII, quando se criaram pequenas unidades fabris com vistas a assegurar o consumo corrente $^{111}$. Por outro lado, em 1804, publicou-se em Lisboa a obra Arte

105 CASTRO, Nuno. A porcelana chinesa e os brasões do Império. Porto: Civilização, 1987, p. $203,207,212$ e 213.

106 CASTRO, Nuno. A porcelana chinesa [...], p. 183-215; Idem. Porcelana chinesa e alguns brasões inéditos. Companhia das Índias. Porcelanas. Organização Rui Guedes. Lisboa: Bertrand, 1995, p. 101-104. Em qualquer dos trabalhos, podem ver-se reproduções a cores das peças.

107 CASTRO, Nuno. A porcelana chinesa [...], p. 219-230.

108 LICHNOWSKY, Félix. Portugal. Recordações do ano de 1842. Prefácio e notas de Castelo Branco Chaves. Lisboa: Ática, 1946, p. 74.

109 Vista Alegre. Porcelanas [...], p. 96.

110 II Leilão Vista Alegre [...], p. 62-63.

111 Uma nota manuscrita, na folha de guarda de um exemplar da Arte do louceiro, presumivelmente da autoria de Simão José Fernandes (1793-1845) ou de Filipe Joaquim Accioli (18..), antigos possuidores da obra, indica: "Em 1777 se estabeleceo no sitio do Cavaquinho ao pé do Porto huma fabrica 
do louceiro ou Tratado sobre o modo de fazer as louças de barro mais grossas, uma tradução de um texto francês, da autoria de José Ferreira da Silva, mandada efectuar por D. João VI, na qualidade de príncipe regente ${ }^{112}$.

Durante o século XIX, algumas obras de cozinha, de economia doméstica e de higiene e saúde deram conta das que eram entendidas como melhores opções relativamente aos materiais em que os recipientes para cozinhar e servir os alimentos deveriam ser confeccionados. Assim, por exemplo, Francisco de Mello Franco, em obra publicada no início do século XIX, sobre questões que aliavam a higiene e a saúde, considerou que os utensílios de cozinha não deviam ser de cobre, chumbo ou estanho pois, embora duráveis, ganhavam verdete, "um verdadeiro veneno para o homem", o qual causava problemas de estômago, podendo mesmo provocar a morte. Defendeu os recipientes de ferro, folha de flandres e barro ${ }^{113}$. Em 1818, foi a vez de José Pinheiro de Freitas Soares dedicar um dos capítulos da sua obra Tratado de Policia Médica aos objectos de cozinha utilizados para preparar ou guardar alimentos. As observações que teceu foram no mesmo sentido, isto é, defendeu o uso de objectos de barro não vidrado, prata, bom estanho, ferro batido e lata ou folha de flandres. Por seu lado, condenou o uso de peças de barro de verniz ordinário, de cobre, de chumbo e de estanho com grande liga de chumbo devido aos malefícios que ofereciam à saúde das populações, em especial das mais carenciadas, as que eram as principais consumidoras deste tipo de bens ${ }^{114}$.

de loica de pó de pedra por privilegio exclusivo de dez annos conferido ao Dr. Vandelli. Houve outra prorogação daquele privilegio em 1787 em sete de fevereiro com inzenção de meios directos sobre os materiais necesarios á fabrica. Em 1793 outra prorogação de dez annos com inzenção de meios directos d'entrada nos Portos do Brasil. O Dr. Vandelli recebia a 1/5 parte do produto desta fabrica, cujo rendimento lhe dava por anno 1,000,000 reis". Cf. na Biblioteca Nacional de Portugal, o exemplar cuja cota é S.A. 15703 P. Agradecemos à Senhora Dr. Maria Leonor Antunes, nossa antiga aluna e actualmente orientanda de Mestrado, a indicação destas informações. Sobre as fábricas implantadas a partir da segunda metade do século XVIII, cf. PEDREIRA, Jorge. Estrutura industrial e mercado colonial. Portugal e Brasil (17801830). Lisboa: Difel, 1994.

112 Arte do louceiro ou Tratado sobre o modo de fazer as louças de barro mais grossas. Trad. do francês por José Ferreira da Silva. Lisboa: Impressão Régia, 1804.

113 FRANCO, Francisco de Mello. Elementos de hygiene, ou dictames para conservar a saúde, e prolongar a vida. 2. ed. Lisboa: Tipografia da Academia, 1819, p. 161-162. A primeira edição foi de 1814.

114 SOARES, José Pinheiro de Freitas. Tratado de Policia Médica, no qual se comprehendem todas as matérias, que podem servir para organizar hum regimento de policia da saúde, para o interior do Reino de Portugal. Lisboa: Tipografia da Academia Real das Ciências, 1818, p. 183-196. 
O visconde de Vilarinho de São Romão, António Lobo Barbosa Teixeira Ferreira Girão, ao publicar anonimamente, em 1841, a obra Arte do cosinheiro e do copeiro ${ }^{115}$, profundamente influenciada por uma obra francesa de $1822^{116}$, deteve-se igualmente nos recheios dos locais onde se preparavam os alimentos. Uma das estampas incluídas no texto referiu-se a uma bateria de cozinha, com o desenho dos diversos objectos que a deveriam compor, entre os quais se conta um clibano, fogão inventado pelo próprio visconde. $\mathrm{O}$ autor também incluiu algumas reflexões acerca do uso quotidiano da louça:

[...] toda a pessoa de juízo por mais rica e abastada que seja deve ser económica e por isso não é indiferente o usar desta ou daquela louça diariamente. A faiança de nossas fábricas é muito imperfeita, racha toda em pouco tempo, tem muito mau vidrado e tão carregado no chumbo que pode ser atacado pelo vinagre de escabeches. Além disso a sua pouca duração faz com que se tenha gastado mais no fim de cinco ou seis anos, do que se usasse sempre louça da Índia. Quando eu falo de louça da Índia, entenda-se que é a da ordinária azul e não das porcelanas mais caras, pois essas não se podem comparar com as nossas grosseiras manufacturas. Um prato de guardanapo desta louça azul da Índia custa 200 réis, mas se for bem tratado pode durar em serviço contínuo dez anos, sempre bom e vistoso; um prato de faiança custa 40 réis, mas passados seis meses está denegrido, rachado e incapaz de servir; logo o prato da Índia vale por vinte de faiança e fica mais barato. Depois da louça da Índia eu não conheço melhor louça do que a de faiança pintada de azul que vem de Inglaterra, e até excede na pintura e na beleza do azul a mesma louça da Índia. Esta é muito boa para o uso ordinário e tem muita duração, posto que seja cara vem a ficar mais barata do que a nossa faiança e até mesmo que a branca inglesa, a experiência de alguns anos mo tem confirmado ${ }^{117}$.

115 Arte do cosinheiro e do copeiro compilada dos melhores auctores, que sobre isto escreveram modernamente sendo a parte principal extrahida da obra que tem por titulo La Maison de Campagne publicada em 1822 por Madame Aglae Adanson dada á luz por um amigo dos progressos da civilização. Lisboa: Tipografia da Sociedade Propagadora de Conhecimentos Úteis, 1841.

116 BRAGA, Isabel M. R. Mendes Drumond. Mulheres que influenciam homens: Aglae Adanson e o Visconde de Vilarinho de São Romão. Vivências no feminino. Poder, violência e marginalidade nos séculos XV a XIX. Lisboa: Tribuna da História, 2007, p. 201-209.

p. 319-320.

117 [VISCONDE DE VILARINHO DE SÃO ROMÃO]. Arte do cosinheiro e do copeiro [...], 
Os anúncios publicados nos periódicos faziam igualmente referência aos diversos tipos de louça que se podiam adquirir. Em O Grátis, podem ler-se anúncios como os seguintes: "vende-se na rua do Príncipe n. ${ }^{o}$ 63-64 um jogo de louça do Japão com figuras encarnadas para mais de 50 pessoas" 118 "no Pelourinho vende-se por preços cómodos para liquidar a louça da Índia e inglesa e charões no armazém n. ${ }^{\circ} 20$ ao pé do escritório do Omnibus" 119 , ou ainda "na fábrica de louça fina de Silva Lisboa, rua do Cura, $n .^{\circ} 32$, às Trinas, se fabricam e vendem peças de louça próprias para os usos domésticos. A sua boa qualidade, pois resistem muito ao calor, e o seu cómodo preço lhe devem dar preferência e estimação" ${ }^{120}$. Mais extenso era o anúncio da fábrica da Vista Alegre, a qual tentava conquistar um público diversificado: "A porcelana da fábrica da Vista Alegre tem progressivamente melhorado em qualidade à proporção que os seus preços têm consideravelmente baixado e pode hoje equiparar-se à melhor porcelana estrangeira. Nos armazéns da mesma fábrica, na rua Direita da Boa Vista n. ${ }^{\circ} 4 \mathrm{P}$, acharão os compradores um variado sortimento de louça para serviço tanto de chá como de mesa, em branco, dourado e pintado, imitando a porcelana francesa e a da China por preços tão baixos que tornam sumamente preferível o uso desta louça ao da louça de pó de pedra, por isso que sendo incontestável a superioridade da consistência, duração e beleza da porcelana, o seu preço é hoje quase igual e talvez inferior ao de pó de pedra". O mesmo anúncio informava acerca dos preços praticados: pratos brancos de 620 a 960 réis a dúzia, pratos pintados, imitando louça de Cantão, de 1.080 a 2.880 réis. Com preços mais elevados a louça pintada e dourada ${ }^{121}$.

5. Algumas reflexões finais. Independentemente das fontes - bem mais abundantes no século XIX do que nos períodos anteriores -, livros de cozinha, obras de economia doméstica e de higiene e saúde, a par de publicidade, inventários de bens, iconografia diversa e dos próprios objectos que chegaram até o presente, é muito clara a contínua complexificação da bateria de cozinha: cada vez mais objectos, com funções específicas, uns criados para responder a novos hábitos (tais como os bules, as cafeteiras, as

118 O Grátis. Jornal de Annuncios e do Comercio, n. 41, Lisboa, 29 de março de 1837.

119 O Grátis. Jornal de Annuncios e do Comercio, n. 293, Lisboa, 19 de janeiro de 1839.

120 O Grátis. Jornal de Annuncios e do Comercio, n. 293, Lisboa, 19 de janeiro de 1839.

121 O Grátis. Jornal de Annuncios e do Comercio, n. 1930, Lisboa, 3 de fevereiro de 1846. 
chocolateiras, as chávenas e os açucareiros) e outros pensados e produzidos para facilitar a vida dos que manuseavam e preparavam os alimentos (como, por exemplo, pequenas máquinas para ralar e moer). Por outro lado, à quantidade e diversidade juntam-se as questões da qualidade e dos materiais. Uma casa abastada não só tinha muitos e diversificados recipientes, como os que possuía, especialmente os que iam à mesa, eram de materiais caros e até nobres, caso das porcelanas, dos cristais e das pratas.

Se o consumo de determinados alimentos evidenciava status, poder de compra e luxo, o mesmo se pode afirmar em relação à posse dos recipientes para preparar e, sobretudo, para servir os alimentos e as bebidas. Afinal, por exemplo, a posse de um serviço de chá revelava, desde logo, um hábito dispendioso, inerente ao consumo de uma bebida exótica, e o poder aquisitivo de alguém que podia investir num conjunto de objectos que não eram de primeira necessidade, evidenciando a pertença a um determinado grupo. Em suma, tal como referimos no início deste texto, torna-se evidente que a bateria de cozinha e a baixela de cada um evidenciam vivências e situações, nomeadamente actos e hábitos de sociabilidade, ou seja, podem ser entendidas como critério para aferir o estatuto social dos seus possuidores.

Recebido em agosto de 2010. Aprovado em agosto de 2010. 